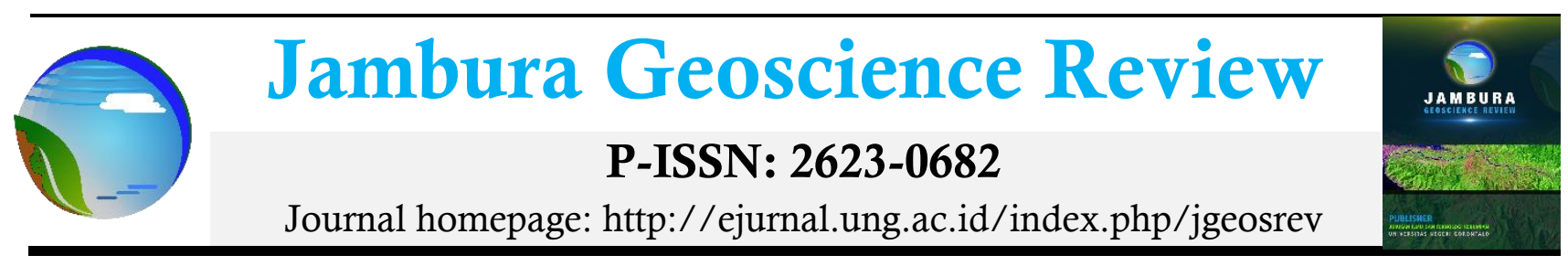

\title{
GEOLOGI DAERAH GEOTHERMAL PANGI KABUPATEN BONE BOLANGO PROVINSI GORONTALO
}

\author{
Dewi Darmayanti Tolodo ${ }^{a}$, Fauzul Chaidir A. Usman ${ }^{a}$, Intan Noviantari Manyoe ${ }^{a}$, Fitra Akbar \\ Gaib $^{\mathrm{a}}$, Fitri Handayani Putje, Yusran Ibrahim
}

${ }^{a}$ Teknik Geologi, Universitas Negeri Gorontalo, Jl Jendral Sudirman No.6, Kota Gorontalo 96128, Indonesia

\section{INFO ARTIKEL}

\section{Status artikel:}

Diterima: 20 Desember 2018

Disetujui: 8 Januari 2019

Tersedia Online: 31 Januari 2019

\section{Keywords:}

Geology, Gorontalo, Manifestasi

Geothermal, Pangi

\section{Penulis korespondensi:}

Dewi Darmayanti Tolodo

Teknik Geologi, Universitas Negeri

Gorontalo, J1 Jendral Sudirman No.6,

Kota Gorontalo 96128, Indonesia

Email:

dewidarmayantitolodo@gmail.com

\begin{abstract}
Geothermal is associated with volcanic that still has heat energy below the surface. Indonesia is a country with geothermal energy reserves of around $40 \%$. There are 256 potential geothermal areas and only 7 locations have been utilized. Gorontalo has several geothermal manifestations, such as Lombongo, Pangi, Libungo, and Hungayono. The purpose of this study was to study the geology of the geothermal manifestations of Pangi, East Suwawa District, Bone Bolango Regency, Gorontalo Province. The research method is divided into field observations, laboratory analysis, and studio analysis. The results of this research show that the geomorphology in the study area is divided into 3 units, namely the Fluvial Plain, the Volcanic Hills, and the Structural Use Landscape. Alluvial Deposition Unit, Volcanic Breccia Unit, Tuff Lapili Unit, Andesite Unit, Granodiorite Unit, and Porphyry Diorite Unit.
\end{abstract}

Copyright (C) 2019 JGeosREV-UNG This open access article is distributed under $a$ Creative Commons Attribution (CC-BY) 4.0 International license

\section{Pendahuluan}

Indonesia termasuk dalam jalur gunungapi Pasifik (Pasific Ring of Fire) yang disebabkan oleh adanya interaksi antara lempeng Eurasia, Pasifik, dan India-Australia (Morley, 2012). Kondisi ini menjadikan Indonesia menjadi salah satu negara dengan cadangan energi geothermal yang melimpah, yakni sekitar 40\%. Berdasarkan data Badan Geologi (2009), terdapat 256 daerah potensi geothermal dan hanya 7 lokasi $(2,64 \%)$ yang telah dimanfaatkan.

Pulau Sulawesi merupakan pulau yang terbentuk dari interaksi tiga lempeng besar, yaitu lempeng Eurasia, Pasifik, dan Australia sejak masa Mesozoikum (Szentpeteri, 2015). Gorontalo terletak pada Lengan Utara Sulawesi yang merupakan busur kepulauan magmatik (island arc) akibat subduksi Laut Sulawesi dan Subduksi Laut Maluku (Maulana, 2013). Adanya aktivitas magmatisme ini menyebabkan Gorontalo memiliki beberapa titik manifestasi geothermal yang berada di Kabupaten Bone Bolango yakni Lombongo, Pangi, Pancuran, dan Hungayono (Badan Geologi, 2009).

Penelitian Manyoe (2017) terkait geothermal di daerah Suwawa, Kabupaten Bone Bolango, Gorontalo masih belum dapat menjelaskan mengenai potensi yang dapat dikembangkan sehingga perlu dilakukan penelitian lebih lanjut untuk memperoleh informasi yang lebih mendalam dan lebih akurat. Daerah geothermal, sistem, dan batuan reservoirnya dibedakan berdasarkan suhu, entalpi, dan kondisi fisik. Suhu suatu sumber daya geothermal menentukan teknologi yang akan digunakan dalam pemanfaatan energi panas yang dihasilkan (Parada, 2013).

Pemanfaatan potensi geothermal terbagi atas pemanfaatan langsung dan pemanfaatan tidak langsung. Pemanfaatan langsung termasuk dalam penggunaan di sektor non-listrik seperti bidang pertanian, perikanan, kesehatan, dan lain-lain. Sedangkan pemanfaatan tidak langsung ialah sebagai Pembangkit Listrik Tenaga Panas Bumi (PLTP). 
Energi geothermal dapat menyediakan sumber tenaga yang bersih dan terbarukan, serta dapat memberikan keuntungan yang signifikan. Emisi energi geothermal tak mengandung polutan kimiawi atau tak mengeluarkan limbah, dan hanya mengandung sebagian besar air yang diinjeksikan kembali ke dalam bumi (Citrosiswiyono, 2008). Pemanfaatan energi geothermal diawali dengan eksplorasi daerah geothermal untuk mengetahui besarnya sumber daya geothermal agar dapat dimanfaatkan pada sektor listrik maupun non-listrik. Eksplorasi energi geothermal yang dapat dilakukan adalah survey geologi, geokimia dan survei geofisika. Eksplorasi merupakan faktor penting dalam klasifikasi sistem geothermal sekaligus pemanfaatannya (Moeck, 2014). Tujuan dari penelitian ini ialah untuk mengetahui geologi daerah geothermal Pangi Kecamatan Suwawa Timur Kabupeten Bone Bolango Provinsi Gorontalo.

\section{Metodologi}

\subsection{Lokasi penelitian}

Penelitian ini dilakukan pada daerah geothermal yang ada di kabupaten Bone Bolango, Provinsi Gorontalo (Gambar 1). Pengambilan data difokuskan pada beberapa titik di sekitar manifestasi geothermal Pangi dan sekitar objek wisata Lombongo.

\subsection{Metode penelitian}

Metode dalam penelitian ini adalah melakukan observasi geologi lapangan, analisis laboratorium dan analisis studio. Observasi geologi lapangan yaitu dengan mengumpulkan data geologi, struktur geologi dan data manifestasi geothermal permukaan. Data geologi berupa data manifestasi geothermal, geomorfologi, petrologi, petrografi, stratigrafi, dan struktur geologi daerah penelitian. Data yang diperoleh di lapangan dianalisis di laboratorium.

Data geologi yang diperoleh di lapangan berupa data manifestasi geothermal, geomorfologi, petrologi, petrografi, stratigrafi, dan struktur geologi. Analisis karaktersitik fisika dan kimia dilakukan untuk memperoleh data manifestasi geothermal. Analisis bentanglahan daerah penelitian dilakukan di studio untuk memetakan geomorfologi daerah geothermal. Analisis petrologi berupa analisis megaskopis batuan di daerah penelitian. Analisis petrografi berupa analisis mikroskopis menggunakan mikroskop Nikon Cipol. Stratigrafi daerah penelitian dianalisis berdasarkan urutan umur batuan di daerah penelitian. Analisis stratigrafi menghasilkan kolom stratigrafi daerah penelitian. Analisis data struktur geologi diolah menggunakan software Dips.

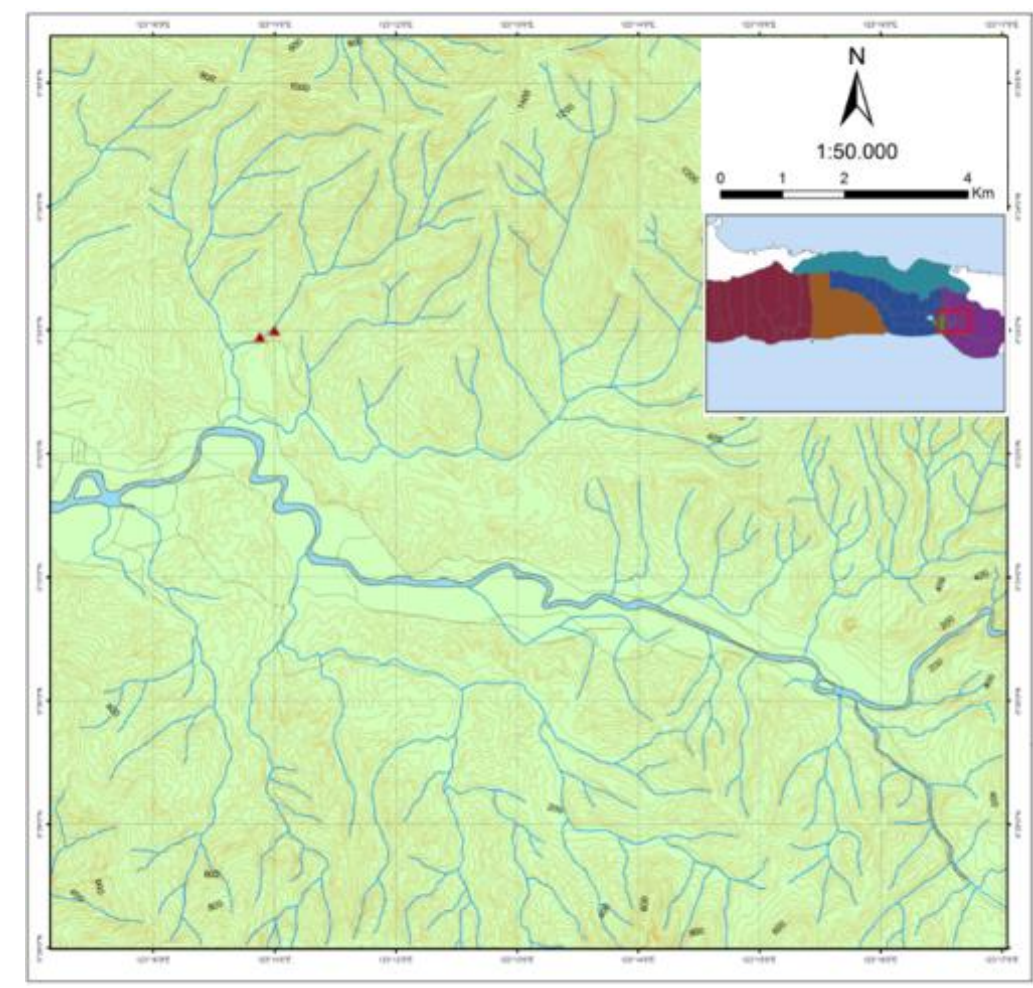

Gambar 1. Peta Lokasi Penelitian 


\section{Hasil dan Pembahasan}

\subsection{Geormofologi}

Berdasarkan interpretasi peta dan pengamatan langsung, kondisi geomorfologi pada daerah penelitian terbagi atas tiga satuan, yaitu Bentuklahan Dataran Fluvial, Bentuklahan Perbukitan Vulkanik, dan Bentuklahan Pegunugan Struktural (Gambar 3). Bentuklahan Dataran Fluvial (Gambar 2.a) mempunyai ciri topografi yang relatif datar. Proses morfogenesa yang bekerja pada daerah ini dipengaruhi oleh proses fluviatil (aktivitas sungai). Hal ini dapat dibuktikan dengan dijumpainya sungai yang berstadia dewasa dan bentuk-bentuk lahan fluvial, antara lain; channel bar, cut bank, dataran banjir, point bar dan tanggul alam.

Bentuklahan Perbukitan Vulkanik (Gambar 2.b) mempunyai ciri topografi berupa bukit dengan kontur renggang, dan hal ini diperkuat dengan ditemuinya singkapan-singkapan batuan vulkanik seperti tuff dan breksi pada daerah ini. Bentuklahan Pegunungan Struktural (Gambar 2.c) memiliki ciri topografi yang relatif memiliki kemiringan lereng yang curam. Kemudian, hal ini juga tergambarkan pada pola kontur yang rapat. Selain itu pegunungan ini terbentuk akibat dari kontrol struktur. Hal ini dibuktikan pada daerah penelitian dijumpai banyak bidang sesar dan kekar yang mengiindikasikan bahwa pada daerah tersebut terdapat kerja struktur. Satuan bentuklahan ini merupakan daerah konservasi atau hutan lindung.

\subsection{Petrologi dan stratigrafi}

Berdasarkan hasil pengamatan lapangan dan analisis, daerah penelitian tersusun atas enam satuan batuan (Gambar 5) dengan urutan dari yang muda ke yang tua ialah: (1) Satuan Endapan Aluvial (2) Satuan Breksi Vulkanik, (3) Satuan Tuff lapili, (4) Satuan Andesit, (5) Satuan Granodiorit, dan (6) Satuan Diorit Porfiri.

Satuan endapan aluvial (Gambar 4.e) tersusun atas material lepas berukuran lempung - bongkah. Satuan ini terbentuk pada kala Holosen dan prosesnya masih berlangsung sampai sekarang. Satuan breksi (Gambar 4.b) vulkanik dicirikan dengan warna coklat muda, tidak kompak, tersusun atas fragmen batuan andesit dengan matriks berupa tuff. Satuan ini termasuk dalam formasi Batuan Gunungapi Pinogu yang berumur Pleistosen. Satuan tuff lapili (Gambar 4.f) memiliki ciri berwarna putih dengan fragmen berukuran lapili $(2-64 \mathrm{~mm})$, porositas baik, dan kurang kompak. Satuan ini termasuk dalam formasi Batuan Gunungapi Pinogu yang berumur Pliosen.

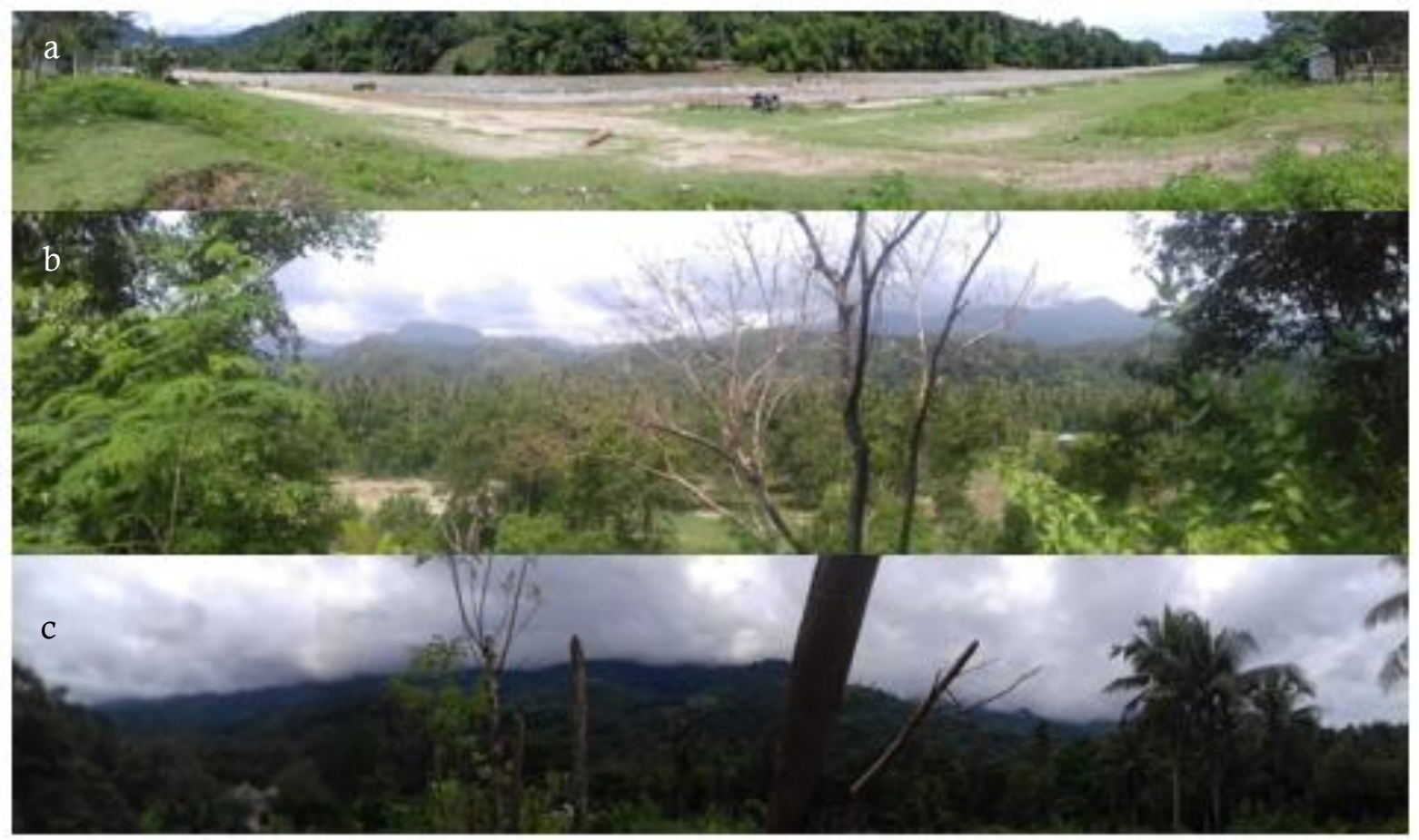

Gambar 2. Bentuklahan Dataran Fluvial di Daerah Penelitian. a) Bentuklahan Dataran Fluvial, b) Bentuklahan Perbukitan Vulkanik, c) Bentuklahan Pegunungan Struktural. 


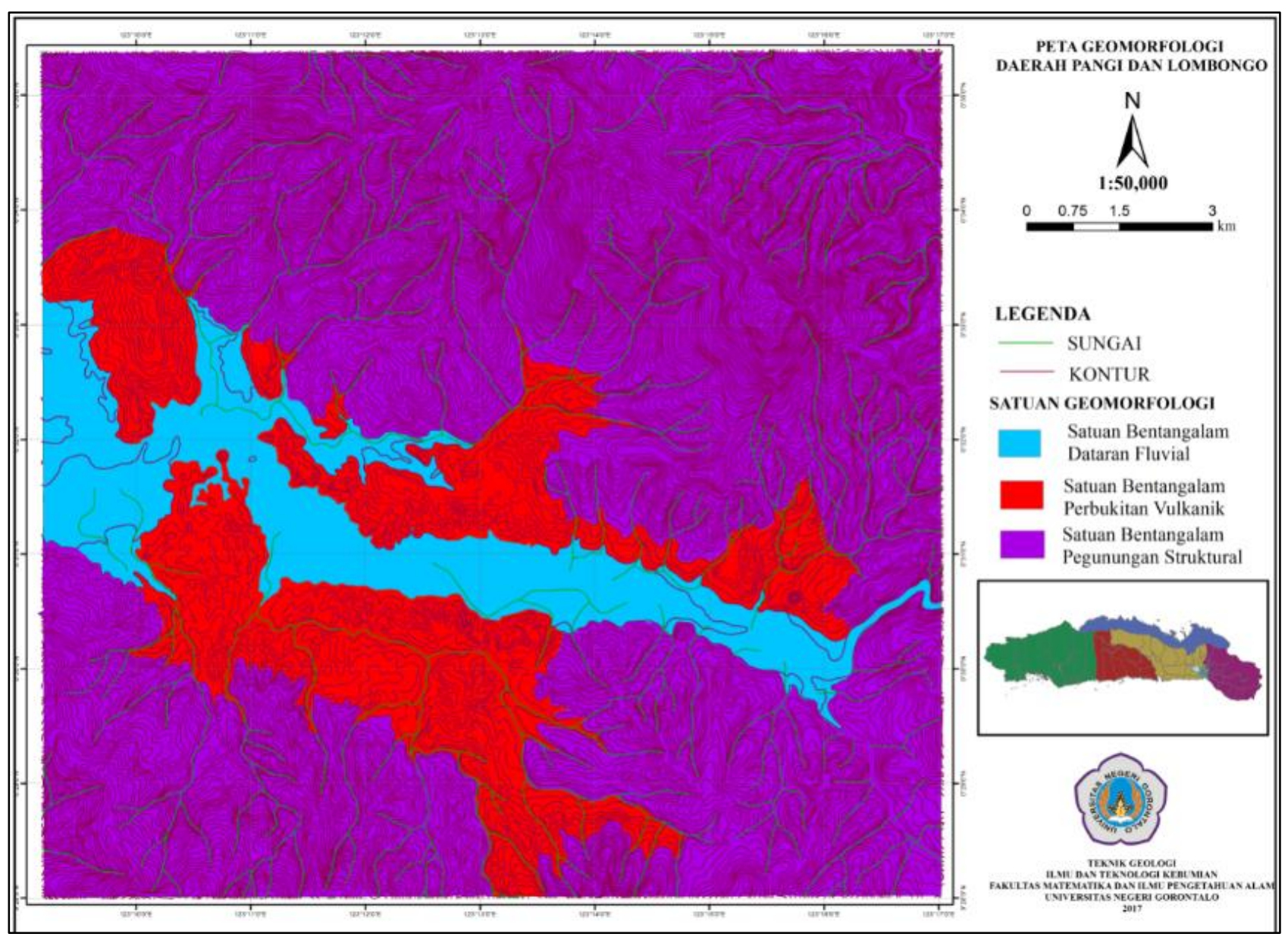

Gambar 3. Peta Geormofologi Daerah Pangi dan Sekitarnya

Satuan andesit (Gambar 4.a) dicirikan oleh warna abu-abu gelap, masif, kompak, bertekstur afanitik dengan dominasi mineral plagioklas. Satuan ini termasuk dalam formasi Batuan Gunungapi Pinogu yang berumur Miosen akhir - Pliosen. Satuan granodiorit (Gambar 4.c) memiliki ciri berwarna abu-abu terang, masif, kompak, dan didominasi mineral plagioklas dan kuarsa. Satuan ini termasuk dalam formasi Batuan Diorit Bone yang terbentuk pada kala Miosen Tengah. Satuan Diorit Porfiri ini memiliki ciri-ciri berwarna abu-abu, massif, kompak, bertekstur porfiritik dengan fenokris Hornblende dan didominasi mineral kuarsa. Satuan ini termasuk ke dalam formasi Diorit Bone dan terbentuk pada kala Miosen Awal.

\subsection{Petrografi}

Analisis petrografi dilakukan pada sampel batuan beku yakni batuan Andesit, Granodiorit, dan Diorit Porfiri. Berdasarkan analisis petrografi, mineral-mineral yang terdapat pada sayatan batuan Andesit (Gambar 6.a) adalah mineral Plagioklas (70\%), Biotit (7\%), Kuarsa (10\%), K-Feldspar (10\%), dan Mineral Opak (3\%). Berdasarkan klasifikasi Travis (1955), batuan dengan dominasi mineral-mineral di atas merupakan batuan andesit yang merupakan batuan beku luar. Berdasarkan hasil pengamatan, pada ketiga batuan ini memiliki mineral dominan berupa kuarsa.

Mineral-mineral yang terdapat pada sayatan batuan Granodiorit (Gambar 6.b) adalah mineral Plagioklas (65\%), Biotit (10\%), Kuarsa (5\%), Hornblende (10\%), Piroksen (8\%) dan Mineral Opak (2\%). Berdasarkan klasifikasi Travis (1955), batuan dengan dominasi mineral-mineral di atas merupakan batuan Granodiorit yang merupakan batuan beku dalam.

Berdasarkan analisis petrografi, mineral-mineral yang terdapat pada sayatan batuan Diorit Porfiri (Gambar 6.c) adalah mineral Plagioklas (41\%), Biotit (10\%), Kuarsa (16\%), Hornblende (20\%), 


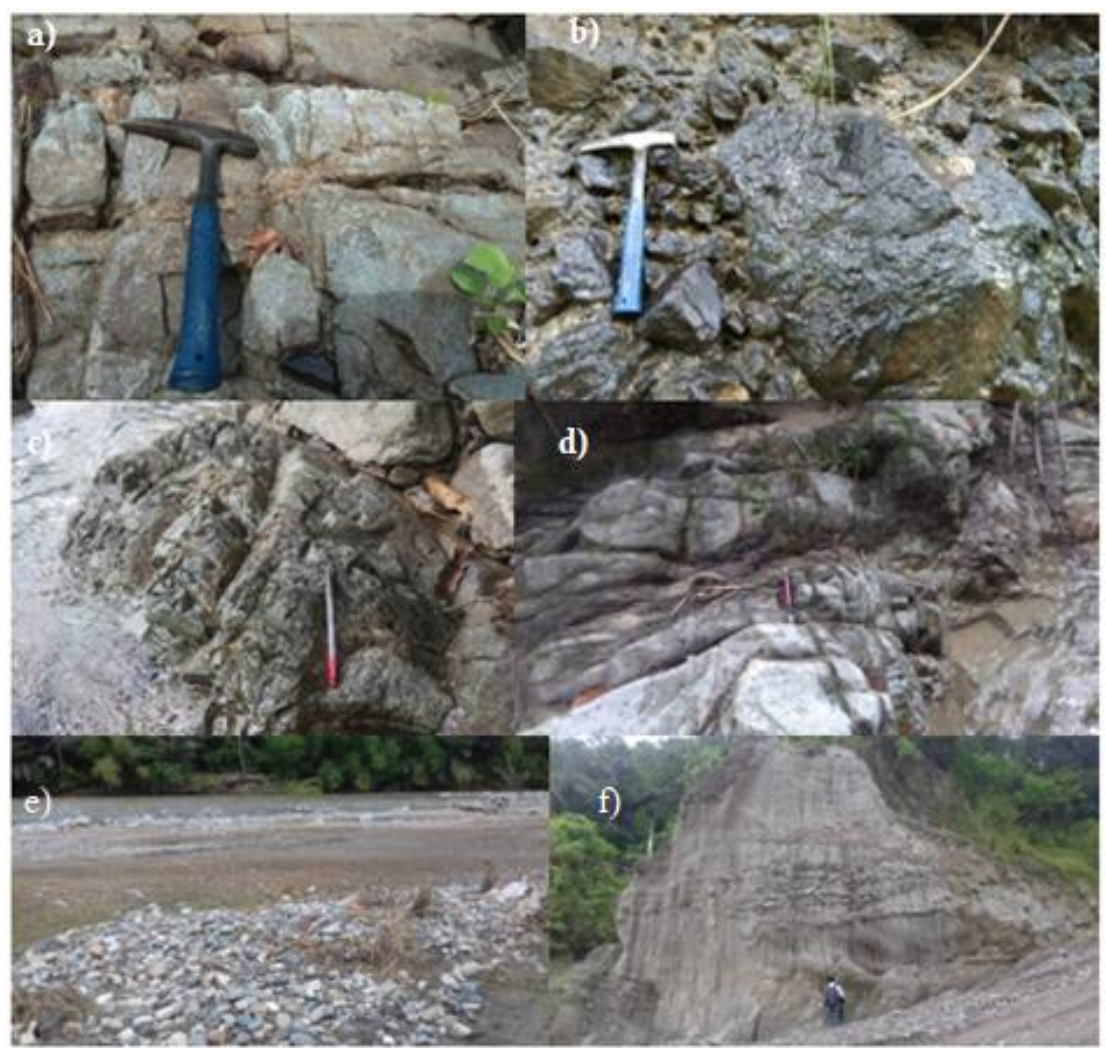

Gambar 4. Singkapan batuan di daerah penelitian (a) Andesit, b) Breksi, c) Granodiorit, d) Diorit Porfiri, e) Endapan Fluvial, f) Tuff)

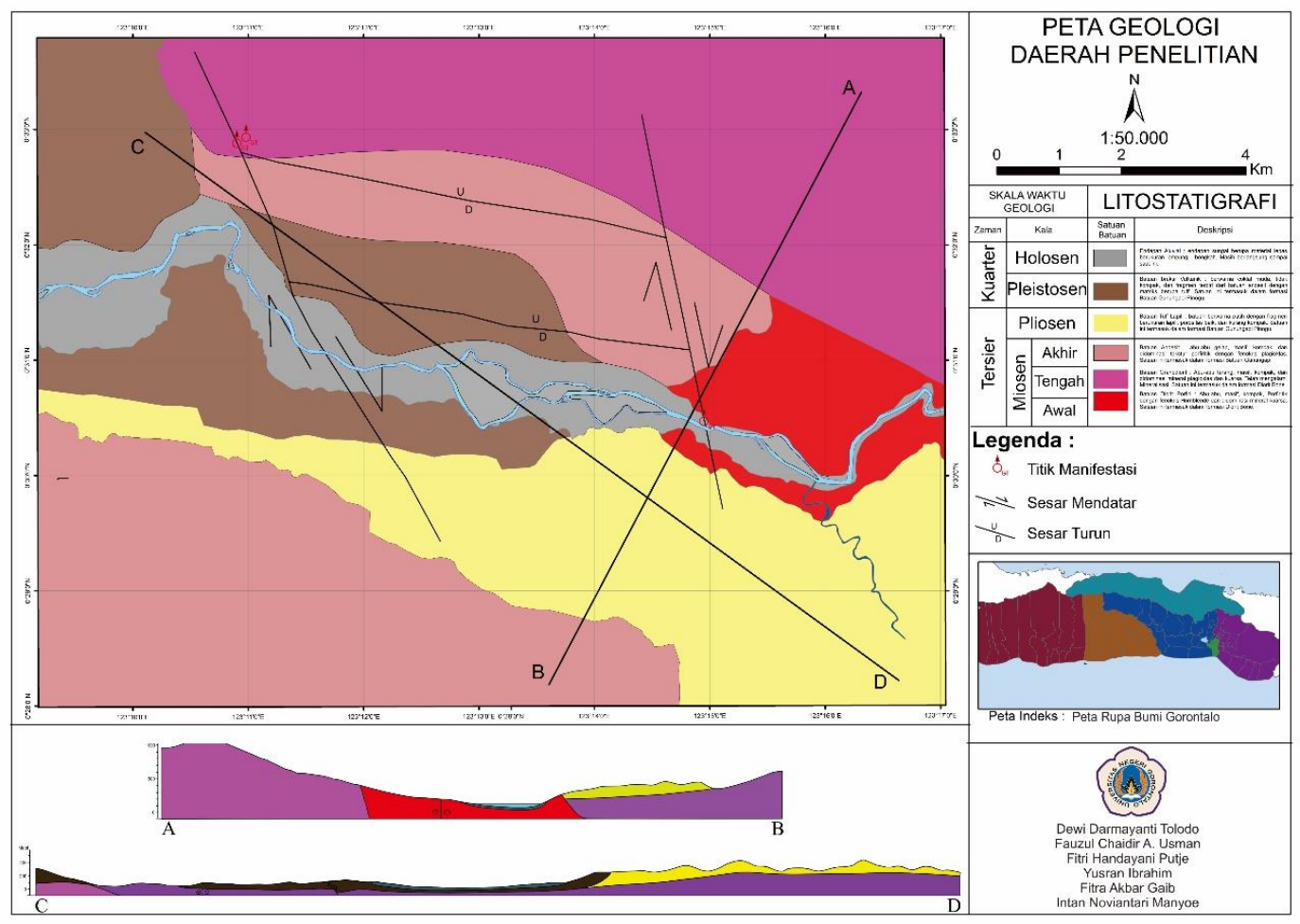

Gambar 5. Peta Geologi Daerah Pangi dan Sekitarnya

Orthoklas (11\%), dan Mineral Opak (2\%). Berdasarkan klasifikasi Travis (1955), batuan dengan dominasi mineral-mineral diatas merupakan batuan Diorit Porfiri yang merupakan batuan beku dalam.

Pengamatan mineral pada sayatan tipis ini dapat menjadi pertimbangan tingkat kelarutan kuarsa pada air panas karena akan berpengaruh pada $\mathrm{pH}$ dimana mineral ini mudah larut dengan air. Keterdapatan mineral ini dapat menjadi bahan pertimbangan untuk pengembangan energi geothermal. 


\section{Kiri}

\section{Kanan}
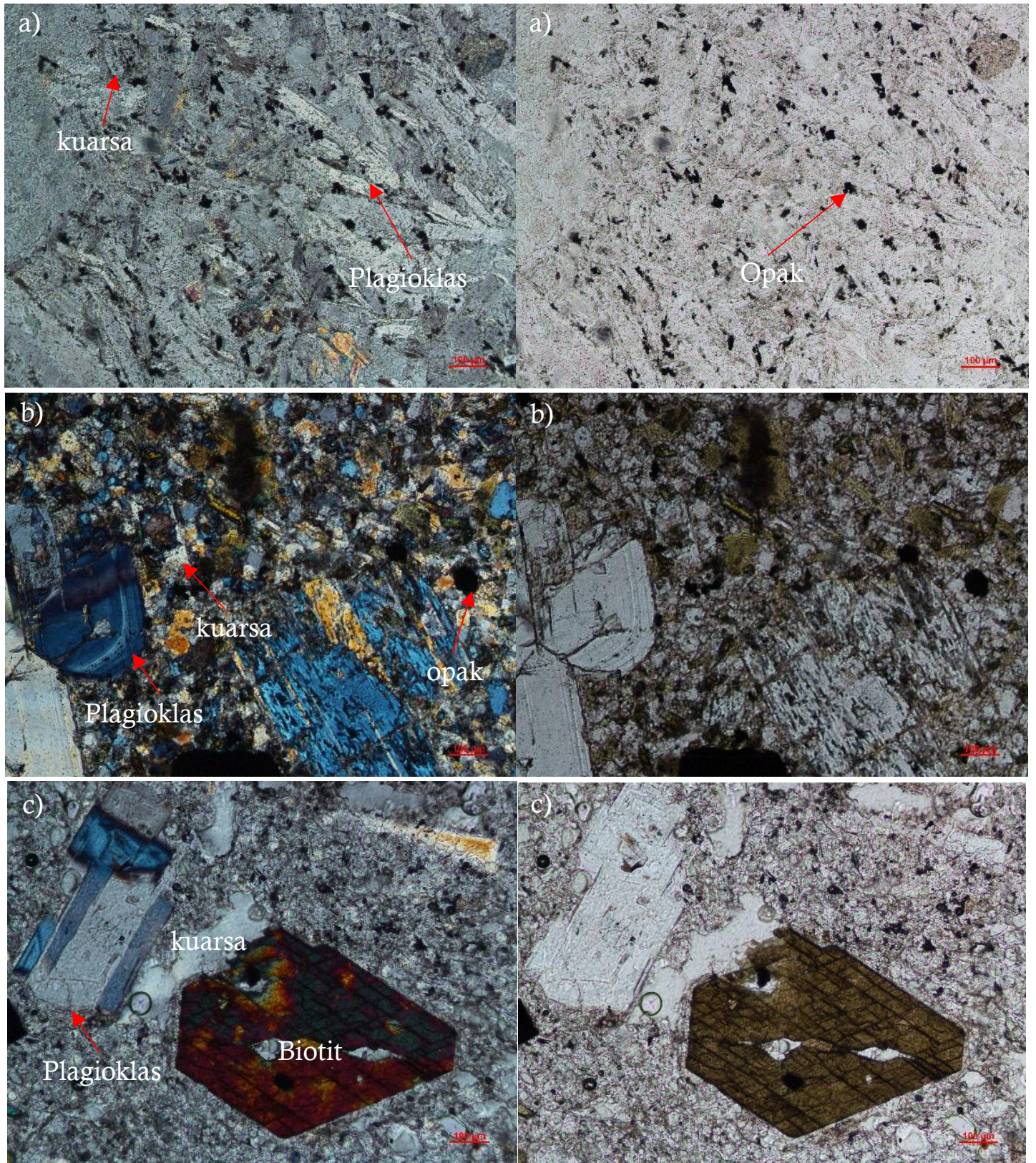

Gambar 6. Kenampakkan Petrografi batuan a) Andesit, b) Granodiorit, dan c) Diorit Porfiri (Kiri: Nikol Silang, Kanan: Nikol Sejajar).

\subsection{Struktur geologi daerah penelitian}

Struktur geologi di daerah penelitian yang dijumpai di lokasi penelitian berupa perubahan kedudukan batuan, meliputi perubahan jurus dan kemiringan, cermin sesar, gores garis, breksiasi, sesar minor, rekahan, dan pergeseran batas satuan. Data yang diperoleh di lapangan kemudian diolah menggunakan metode analisis kinematik untuk mengetahui jenis dan pergerakan struktur (Tabel 1).

Tabel 1. Hasil analisis tegasan pada kekar

\begin{tabular}{llllll}
\hline $\mathrm{N}$ & Struktur geologi & Litologi & $\sigma 1$ & $\sigma 2$ & $\sigma 3$ \\
\hline 10 & Kekar Berpasangan & Andesite & $337 / 25$ & $157 / 57$ & $245 / 04$ \\
24 & Kekar Berpasangan & Granodiorit & $074 / 37$ & $007 / 70$ & $188 / 30$ \\
24 & Kekar Berpasangan & Breksi Vulkanik & $078 / 29$ & $187 / 36$ & $314 / 39$ \\
20 & Kekar Berpasangan & Diorit Porfiri & $223 / 03$ & $128 / 52$ & $326 / 35$ \\
\hline
\end{tabular}


Sesar di daerah penelitian relatif memiliki kesamaan arah struktur (Gambar 9). Sesar yang terdapat di daerah ini diperkirakan merupakan Sesar Pangi dan Sesar Lombongo. Sesar Pangi merupakan jenis sesar mendatar menganan yang dijumpai di bagian barat daerah penelitian berarah NW-SE. Sesar Lombongo merupakan jenis sesar mendatar mengiri yang dijumpai di bagian timur daerah penelitian berarah NW-SE. Sesar Lombongo merupakan struktur yang mengontrol keluarnya manifestasi geothermal di daerah Lombongo. Sesar Pangi merupakan struktur pengontrol keluarnya manifestasi panas bumi di daerah Pangi.

\subsection{Manifestasi geothermal}

Manifestasi yang terletak di daerah Lombongo (Gambar 10a), tepatnya pada koordinat $\mathrm{N}$ $00^{\circ} 32^{\prime} 56.7^{\prime \prime}$ dan E $123^{\circ} 10^{\prime} 52.7^{\prime \prime}$ berupa mata air panas. Suhu air panas berkisar antara $42^{\circ}-48^{\circ} \mathrm{C}$. Sekitar manifestasi air panas terdapat oksida besi dan endapan travertine. Manifestasi di daerah Pangi (Gambar $10 \mathrm{~b}$ ) terletak pada koordinat $\mathrm{N} 00^{\circ} 30^{\prime} 28,4^{\prime \prime}$ dan E $125^{\circ} 14^{\prime} 56.9^{\prime \prime}$. Pada titik pertama, manifestasi geothermal ini berupa mata air panas dengan suhu $56^{\circ} \mathrm{C}$, endapan berupa oksida besi. Titik manifestasi kedua berjarak $\pm 10 \mathrm{~m}$ dari titik manifestasi pertama. Pada titik ini manifestasi geothermal yang berupa mata air panas memiliki suhu $47^{\circ} \mathrm{C}$.

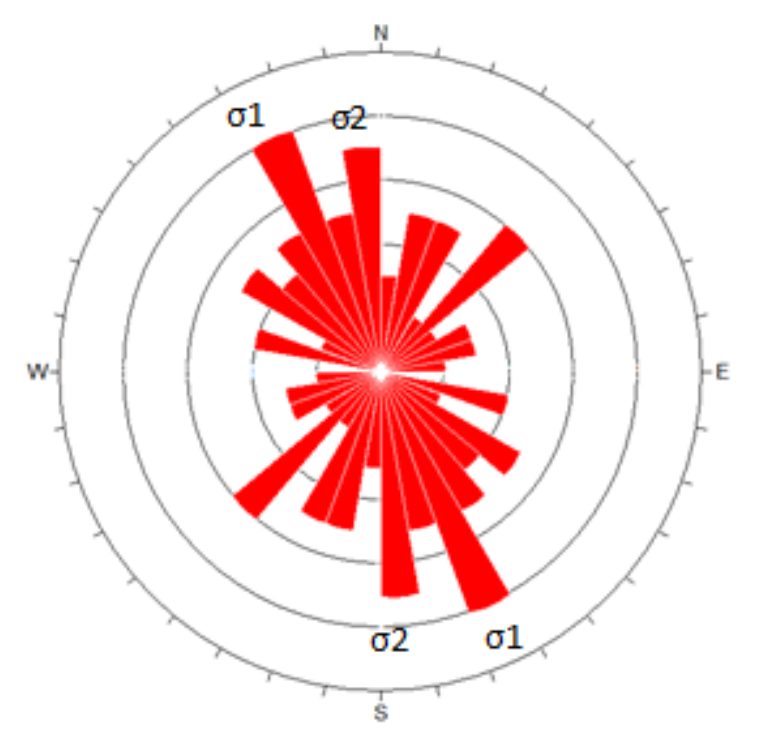

Gambar 9. Diagram arah utama tegasan struktur penelitan yang berarah relatif utara selatan $\sigma 1$ (Sesar Pangi) dan $\sigma 2$ Sesar Lombongo.
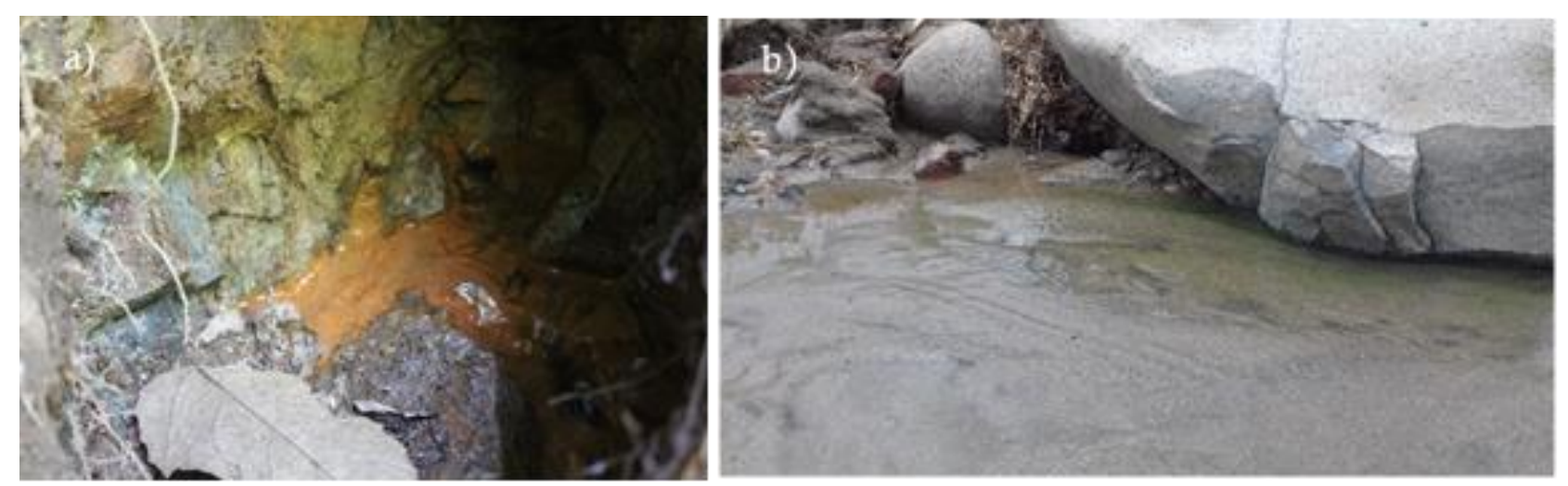

Gambar 10. a) Manifestasi geothermal berupa mata air panas di daerah Lombongo, b) Manifestasi geothermal berupa mata air panas di daerah Pangi. 


\section{Kesimpulan}

Geomorfologi daerah penelitian terdiri dari tiga satuan bentuklahan yaitu Bentuklahan Dataran Fluvial, Bentuklahan Perbukitan Vulkanik, dan Bentuklahan Pegunungan Struktural. Litologi daerah penelitian tersusun atas enam satuan batuan dengan urutan dari muda ke tua yaitu Satuan Endapan Aluvial, Satuan Breksi Vulkanik, Satuan Tuff lapili, Satuan Andesit, Satuan Granodiorit, dan Satuan Diorit Porfiri. Struktur Geologi di daerah penelitian yang diduga sebagai pengontrol keluarnya mata air di daerah penelitian adalah Sesar Pangi dan Sesar Lombongo yang relatif berarah NW-SE. Manifestasi di daerah penelitian memiliki suhu yang berbeda, manifestasi Lombongo memiliki suhu $42^{\circ}-48^{\circ} \mathrm{C}$ dan manifestasi Pangi $47^{\circ}-56^{\circ} \mathrm{C}$.

\section{Ucapan Terima Kasih}

Ucapan terima kasih peneliti sampaikan kepada Kementrian Riset Teknologi dan Pendidikan Tinggi Direktorat Jendral Pembelajaran dan Kemahasiswaan yang telah mendanai penelitian ini.

\section{Referensi}

Badan Geologi. (2009). Geothermal di Indonesia: http://psdg.bgl.esdm.go.id [20 Juni 2017].

Citrosiswiyono, W. (2008). Geothermal dapat Mengurangi Kebutuhan Bahan Bakar Fosil dalam Menyediakan Listrik Negara. Pusat Studi Kebumian dan Bencana LPPM, Surabaya.

Manyoe, I. N. (2017). Kajian Geologi Daerah Panas Bumi Lombongo Kabupaten Bone Bolango Provinsi Gorontalo. Jurnal Geomine, 5(1).

Maulana, A., Watanabe, K., Imai, A., and Yonezu, K. (2013). Origin of magnetite- and ilmenite-series granitic rocks in Sulawesi, Indonesia: magma genesis and regional metallogenic constraint. Procedia Earth and Planetary Sciences, pp 50-57.

Moeck. (2014). Catalog of Geothermal Play Types based on Geologic Controls. Renewable and Sustainable Energy Reviews, pp. 867-882.

Morley, C.K. (2012). Late Cretaceous-Early Palaeogene Tectonic Development of SE Asia. Earth Sciences Reviews, pp 37-75.

Parada, A.F.M. (2013). Geothermal Binary Cycle Power Plant Principles, Operation and Maintenance. Report 20, pp. 443-476.

Szentpeteri, K., Albert, G., and Ungvari, Z. (2015). Plate tectonic and stress-field modelling of the North Arm of Sulawesi (NAoS), Indonesia, to better understand the distribution of mineral deposits styles. Conference Paper. Society of Economic Geologists 2015 Conference.

Travis B. Russel. (1955). Classification Of Rocks. Colorodo School Of Mines. United State Of America. 